\title{
Empowerement of Mompreneurs in Creating Economic Independence
}

\author{
Meilani Dhamayanti ${ }^{1,{ }^{*}}$, Evi Susilawati ${ }^{2}$, Mavianti ${ }^{3}$, Jelita $^{4}$, Nurul Pujiastuti ${ }^{5}$, \\ Marni Br Karo ${ }^{6}$ \\ ${ }^{1}$ Department of Communication Science, Bina Nusantara University, Jakarta, Indonesia \\ ${ }^{2}$ Faculty of Education and Teaching Training, Universitas Islam Sumatera Utara, Indonesia \\ ${ }^{3}$ Faculty of Islamic Religion, Universitas Muhammadiyah Sumatera Utara, Indonesia, \\ ${ }^{4}$ IAIN Langsa, Indonesia \\ ${ }^{5}$ Nursing Major, Poltekkes Kemenkes Malang, Indonesia \\ ${ }^{6}$ Midwifery Program at Medistra Indonesia STIKes, Bekasi, Indonesia \\ ${ }^{*}$ Corresponding author. Email: meilani.dhamayanti@binus.ac.id
}

\begin{abstract}
Women have an important role in household economic resilience. Women are required not only as household managers but also as protector of the family's economic stability. The phenomenon of housewives who build the business world has become a trend. The fact shows many women success build a business in the home industry and earning income. The purpose of this paper is how to empower mompreneurs in creating economic independence. This paper uses concepts and theories about women's empowerment in the social and economic fields. The method used is descriptive qualitative with in-depth interview data collection techniques. The conclusion shows the empowerment of women who have a household industry is needed to improve their entrepreneurial and business skills.
\end{abstract}

Keywords: Empowerment, entrepreneurs, mompreneurs, Independent Economy Telehealth, business, Covid-19

\section{INTRODUCTION}

The phenomenon of mompreuner is currently often found in various cities in Indonesia. Women are not only busy taking care of household matters but also building businesses to support the family economy. Various facts show that the home industry business has enormous potential. The activity of women in building a business is something that must be appreciated. The role of women in creating businesses automatically is not only contributing to the household economy but also opening job opportunities.

Based on the survey conducted by Google shows that Indonesian women prefer entrepreneurship compared to 12 other countries such as Argentina, Brazil, Japan, Kenya, Korea, Malaysia, Mexico, Nigeria, and Vietnam. And this is evidenced by data from the Central Statistics Agency (BPS) which states that the portion of MSMEs managed by women was $64.5 \%$ of the total MSMEs in Indonesia in 2018, or reached 37 million MSMEs. The survey was conducted from January to February 2020 in
12 countries ranging from Latin America, Southern Africa, to the Asia Pacific, it is known that there are two major motives why women want to become entrepreneurs, namely financial problems and family stability. Women prefer to increase their income so that they can achieve financial independence and the needs of their families are also met. So these two things are the focus of Indonesian women's motives. However, most of the businesses run by women are still in the micro, informal, and even ultra-micro sectors, which do not have access to the digital world. This of course needs special attention for them [1].

In the current pandemic era, the role of women in the household has its own challenges. Especially if the spouse is a victim of the impact of termination of employment (PHK) because the company where he works is also affected by this pandemic. So that becoming an impromptu mompreneur is an option for the fulfillment of kitchen needs. And in this completely online era, this is the right time for action and constantly upgrading yourself to be able to compete and stay productive and productive during the pandemic. 
There is a lot of information through social media that offers a variety of options to be able to keep earning during the pandemic without capital. Indeed, capital is still needed but not in the form of money that can be exchanged for goods that can be traded. But more capital in the form of intentions and quotas (which still need money to be able to get it). Intention is the first step to keep moving and taking action in an effort to help the family economy. Because without intention it is impossible to take action that can produce material. Furthermore, quotas, quota utilization must be optimized for positive and productive things. Because there are still women who act as mothers in the household but in the use of quotas they only exist but do not produce.

Based on these problems, the motivation arises to study empirically related to the issue of empowering women to become mompreneurs in order to realize family economic independence by developing research designs that integrate strategic resources and mompreneur empowerment orientation as the basis for implementing strategies so that they can improve the family economy. This is in line with the opinion of experts that in accordance with the views of experts in the field of economics that the involvement of women in the economic sphere will make a major contribution to family welfare, especially in the economic field.

\subsection{Mompreneur}

Mompreneurs is a movement that emerged from France towards the end of the 2000s. Members define themselves as women who create businesses or businesses [2] A mix of 'Mothers and Entrepreneurs' according to when many mothers are motivated to establish control over the quality of their work, and the environment. Those who are inflexible and to satisfy their desire to play the role of a good mother. Regardless of conflicting points of view, criticism of the concept of mompreneruship cannot prevent a mother from becoming mompreneruship and continues to develop as an alternative. According to [2] during the last decade, these women began to take concrete actions with their beliefs, which pushed these women towards entrepreneurial activities. Regardless of how successful they are as entrepreneurs, married women cannot be separated from their household responsibilities. In previous research it has been studied that mompreneurs can achieve or maintain life balance with proper time management [3].

\subsection{Empowerment}

According to [1] Empowerment will relate to efforts to eliminate inequality and make decisions for a woman [4]. The choice to work or not for women depends on how the family and themselves perceive the work, as well as the income and social status that has been obtained with dependence to try to fight stereotypes, subordination and marginalization [5]. One of the concepts of empowerment for women's development (Women's Empowerment Criteria or Women's Development Criteria) was coined by Sara Hlupekile Longwe, better known as the Longwe analysis technique. Longwe's analysis technique has been used as a method of empowering women. The involvement of women in empowerment activities will be closely related to the ability to improve conditions in the family economy. Innovative activities will enable them to learn a wide range of skills to earn an income because they are connected to opportunity and innovation. Some of the businesses that have been put in motion can help women earn income and can improve their social status in society [6].

In its application, women's empowerment activities mean that women have the opportunity to participate in improving their economic conditions [7]. Women's right to work can affect their role and contribution in the family (Perempuan et al., 2019) Currently, many women play multiple roles in their lives, such as being housewives and being entrepreneurs. In general, women want to be able to maintain a balance in their roles and prefer jobs that are not too exhausting for work outside the home. One of the chosen professions is to become an entrepreneur. Through entrepreneurship, a mother can help the family economy and also be able to do all household chores, take care of her husband and children, pay attention to the growth and development of children, and educate their children to become useful human beings for their homeland and religion [8].

Empowerment is the process of forming forces from within or outside the individual to participate, share control, and emphasize that the individual acquires the skills, knowledge, and power sufficient to influence his life and the lives of others he cares about [9]. Women's empowerment is an effort to increase women's ability to gain access and control over resources, economy, politics, social, culture, so that women can self-regulate and increase their self-confidence to be able to play a role and participate actively in solving problems, so as to be able to build abilities and self-concept. Women's empowerment cannot be separated from community empowerment, aiming to create an independent society, able to explore and utilize their potential so that they are free from backwardness or poverty [7].

In the current pandemic era, the role of women in the household has its own challenges. Especially if the spouse is a victim of the impact of termination of employment (PHK) because the company where he works is also affected by this pandemic. So that becoming an impromptu mompreneur is an option for the fulfillment of kitchen needs. And in this completely online era, this is the right time for action and constantly upgrading yourself to be able to compete and stay productive and productive during the pandemic. 
There is a lot of information through social media that offers a variety of options to be able to keep earning during the pandemic without capital. Indeed, capital is still needed but not in the form of money that can be exchanged for goods that can be traded. But more capital in the form of intentions and quotas (which still need money to be able to get it). Intention is the first step to keep moving and taking action in an effort to help the family economy. Because without intention it is impossible to take action that can produce material. Furthermore, quotas, quota utilization must be optimized for positive and productive things. Because there are still women who act as mothers in the household but in the use of quotas they only exist but do not produce.

Based on these problems, the motivation arises to study empirically related to the issue of empowering women to become mompreneurs in order to realize family economic independence by developing research designs that integrate strategic resources and mompreneur empowerment orientation as the basis for implementing strategies so that they can improve the family economy. This is in line with the opinion of experts that in accordance with the views of experts in the field of economics that the involvement of women in the economic sphere will make a major contribution to family welfare, especially in the economic field.

Mompreneur is a business run by housewives in running a business without doing it outside the home. They carry out business activities on the sidelines of doing household chores, namely taking care of children and taking care of their husbands. The business that he can run without large capital is an online business because it provides a great opportunity to complete all his work [10]. They don't forget their duties as housewives and can balance their business and responsibilities as a wife. The main goal of a mompreneur to run a business is to help the family's economy become better. Mompreneur makes women become more independent, creative and not dependent on others so that they can increase self-esteem and family finances.

In domestic life, women play a major role in the continuity of household life and can help the economy and family welfare [11].

Therefore, women must be able to explore their knowledge and skills to develop to be more advanced and have career opportunities [12]. With an increase in the participation of working women, it indirectly helps the family economy. With the dual role they have, women must be able to manage time for family and work so that there are no complaints from the family so that work and family can go hand in hand.

\section{METHOD}

This research is a descriptive research with a qualitative approach. Qualitative descriptive method is a research method that focuses on interpretive, naturalistic involvement by understanding, interpreting, phenomena by using and collecting data learned from various empirical studies, case studies, personal experiences, introspection, life stories, interviews, observational, historical, interactional, and visual text that describes the actual condition of the research object [12]. The object of research being researched is mompreuner who builds a business besides being a housewife where productive activities can be done by housewives, one of which is working at home by opening a business. Based on the object of this research, this research focuses on how to empower mompreneurs in creating economic independence.

Data collection techniques in this study are in-depth interviews. where the researcher questions the problem being reviewed in connection with a previously prepared guidebook that is in accordance with the indicators of the problem being studied. This in-depth interview focuses more on the issues studied regarding the empowerment of mompreneurs in creating economic independence. The researcher uses a key person (key information) with the selected criteria, namely: (1) mompreneur, (2) mompreneur works using e-commerce, (3) has had a business for at least six months, (5) is active and continuous in running a business. Data that has been successfully extracted, collected, and recorded in research activities must be ensured for accuracy and truth. Therefore, each data in this study was selected and determined in appropriate ways to develop the validity of the data obtained. Data validation in this study is the degree of accuracy between the data that occurs on the research object and the power that has been reported in this study so that the valid data in this study is data that does not differ between data in the field which is data that actually occurs in the object of research and data that reported by researchers. The development of validity in this study uses triangulation techniques. Triangulation in testing credibility in this study was carried out to check data from various sources, methods, and times. Triangulation in this study uses source triangulation, which means that researchers compare information obtained from one source with other sources. Excavating the same source with different techniques and determining a different (right) time.

\section{RESULT AND DISCUSSION}

\subsection{Women's Family Economy Fighter}

The role of women in maintaining economic resilience is very important. The findings obtained by the author are one of the reasons women enter the business world due to increasingly pressing economic needs. High family needs that are not balanced with family income make women unable to rely solely on their husband's wages. Another fact, the author found that when the 
family economy slumped, women had to bear the heavy burden of covering the family's economic needs and still had to bear domestic work.

The presence of micro-enterprises managed by women is a form of survival mechanism for the poor. Culturally, women are not productive creatures, but because of their poverty, they are forced to join carry out productive activities which are culturally the obligations of the man. Therefore, women's efforts in developing their businesses are not only deal with technical issues of business ability but also related to the problem of the relationship between women and men who are unequal and domineering. The contribution of women microenterprises support the economy of families, communities, and even the pandemic.

A study conducted show that global markets welcome both the various characteristics brought by women entrepreneurs to the international trade arena [9]. These characteristics include the ability of women in building and maintaining relationships and networks in the long run. Their effective communication skills, sensitivity to cultural differences and inappropriate behavior, organizational skills, as well as non-threatening and non-aggressive.

During the Covid-19 pandemic, many companies did layoffs (terminations). The head of the family who terminated his job will greatly affect the family's economy. Conditions like this encourage women to be able to survive and maintain family economic resilience. Women choose to build a business in an effort to save the family economy as the path that is considered the most likely to be done. The reasons that women build businesses are as follows:

Table 1. Reason of Mompreneur Build Business

\begin{tabular}{|c|c|}
\hline No & Reason of Mompreneur Build Business \\
\hline 1. & Increasing needs \\
\hline 2. & Husband jobless \\
\hline 3. & Don't have job experience \\
\hline 4. & Difficult to find a job \\
\hline 5. & Limited skill \\
\hline 6. & Still take care children \\
\hline 7. & Still take care home \\
\hline
\end{tabular}

The data above shows that the reason women build a home industry business is due to economic reasons. The increasing demands of women's needs are the responsibility of women to be able to fulfill them. The burden on women becomes even greater when the husband has to lose his job. For women who have no work experience, it is quite difficult to try to apply for a job. Limited skills make them pessimistic when they have to find work in the company.

From the various facts that the author finds, many mompreneurs have started a business by trial and error. However, there are some who have succeeded. Successful mompreneurs usually develop a business based on their hobbies. The reason of mompreneur choose to build business:

a. The type of business that when starting does not require a large capital stock.

b. The type of business where the transaction and production processes are close to the type of domestic work. Thus, sometimes work

c. Done while doing household chores.

d. The business production process is not complex, does not require heavy equipment expensive, and does not require high technology.

e. Management of profits from operating results, usually used for finance daily life.

Mompreneurs will find it easier to develop a business from their hobbies. The data that the author can find are several types of hobbies that were developed to become business opportunities, namely:

Table 2. Business Opportunity

\begin{tabular}{|c|c|c|}
\hline No & Hobby Prospects & $\begin{array}{c}\text { Business } \\
\text { Opportunities }\end{array}$ \\
\hline 1. & Cooking & culinary \\
\hline 2 & sewing & Garment \\
\hline 3. & Farming & $\begin{array}{c}\text { Fruit or } \\
\text { vegetable } \\
\text { farming }\end{array}$ \\
\hline 4 & Social media person & $\begin{array}{c}\text { Digital } \\
\text { marketing }\end{array}$ \\
\hline 5 & Make up & Make up artist \\
\hline
\end{tabular}

Data shows that building a business from a hobby has big prospects. During the pandemic, many mompreneurs have succeeded in building a culinary business. Cooking for women who are used to doing domestic tasks is a usual routine. The hobby of cooking encourages mompreneurs to build businesses such as catering. The catering business was built by offering selected menus for daily needs. Offers are usually through acquaintances, colleagues, or neighborhood neighbors.

Some mompreneurs who like sewing take advantage of business opportunities by sewing daily clothes and masks. Everiday clothes are a business that has good prospects considering that during a pandemic people 
choose to work at home using comfortable clothes. The mask business opportunity is also very promising because it becomes a necessity during the pandemic.

\subsection{Mompreneur's Obstacles in Developing a Business}

Based on observations, several obstacles must be faced by mompreneurs in starting and building a business. :

a. Access to capital

Capital is always an obstacle in building a business. Mompreneurs also lack information about getting capital support from companies or the government.

b. Marketing

Marketing problems have always been the main reason for market development. Women need to understand how to develop a market so that the product is known and accepted by people. Women's participation in government-supported trade missions is usually minimal.

c. Information

Even though this is the era of digital technology, not everyone understands optimizing it for business needs.

d. Training

e. Many companies care about developing mompreneur skills but not many know how to get them. Various training can be attended by mompreneurs, both organized by the government and companies

f. Access to policymakers

g. There is no doubt that women have different approaches to policy issues. By bringing together women entrepreneurs, business associations can design and conduct -oriented lobbies actions that can influence public policy, as well as help change discriminatory traditional practices.

\subsection{Digital Empowerment}

a. Networking Ability and Reading Market Trends Mompreneurs must increase their ability to recognize business opportunities, one of which is by understanding their own skills and being able to conduct market tests. Be active in networking from the closest community by utilizing a solid network of friends among mothers.

b. Promotional Ability with Digital Marketing Expanding knowledge about tips and tricks for selling via the marketplace. Mompreneurs must also be willing to learn to apply Search Engine Optimization (SEO) on product and store pages. It is also very important to optimize sales by advertising digitally, whether it is advertising in related marketplaces or advertising on social media.

c. Marketing Skills via Social Media

Build a reputation by opening accounts on social media channels such as Facebook, Instagram, TikTok, and WhatsApp. Using no-cost promotional strategies such as barter/endorsement. Mompreneurs can start from nano-influencers in their closest circle. Actively interact with audiences and consumers to build engagement and loyalty.

\section{CONCLUSION}

This study indicates that mompreneur empowerment is very much needed. The empowerment of mompreneurs must involve various institutions such as the government or companies. The empowerment of mompreneurs is not limited to capital but also to increasing women's skills. The results of mompreneur empowerment are not only providing economic and financial independence but at the same time opening up job opportunities and solutions to unemployment and poverty

\section{ACKNOWLEDGMENTS}

For the first and foremost, the writer would like to express her deepest gratitude for Almighty God for his marvelous. And we would like to thank to the Association of KODELN (Collaboration of Lecturers Across Countries) in Indonesia for the support and contribution to this review article so it can be accepted in The International Conference on Social, Economics, Business, and Education (ICSEBE 2021) organized by the University Makassar State (UNM).

\section{REFERENCES}

[1] Barro, R. J. (1991), "Economic Growth in a Cross section of Countries", Quarterly Journal of Economics, 2, pp. 407-433.

[2] Landor, J. (2020). Mompreneurs: Economics, parenting and identity. Travail et Emploi, 2020(special edition), https://doi.org/10.4000/travailemploi.

[3] Byrne, J., Fattoum, S., \& Diaz Garcia, M. C. (2019). Role Models and Women Entrepreneurs: Entrepreneurial Superwoman Has Her Say. Journal of Small Business Management, 57(1), 154-184. https://doi.org/https://doi.org/10.1111/jsbm.12426

[4] Wijaya, L., \& Layman, C. V. (2018). How Do Mompreneurs Achieve Work-Life Balance? (Evidence From Small Business In Tangerang, Entrepreneurship, 6(November), 1-12.

[5] Fitriani, N. (2019). Pemberdayaan Ekonomi Perempuan Terhadap Kemandirian Ekonomi di UKM "Pelangi Nusantara" Singosari Malang. Tesis, 162.

[6] Aritonang, S., Yulieanto, H., \& Rajab, D. D. A. (2018). Jurnal' Pertahanan. Jurnal Pertahanan, 4(1), 61-75. Retrieved from http://jurnal.idu.ac.id/index.php/DefenseJournal/arti cle/view/253/pdf4

[7] Perempuan, P., Kewirausahaan, M., Dalam, S., \& Kemandirian, M. (2019). Hilman Palaon dan Laksmi Andam Dewi, 1-36. 
[8] Haugh, H. M., \& Talwar, A. (2016). Linking Social Entrepreneurship and Social Change: The Mediating Role of Empowerment. Journal of Business Ethics, 133(4), 643-658. https://doi.org/10.1007/s10551014-2449-4

[9] P., Manajemen, M., Sarjana, P. P., \& Diponegoro, U. (2016). Terlibat Dalam Komunitas Indonesia Mompreneur ( Studi Pada Komunitas Indonesia Mompreneur ).

[10] Elburdah, R. P., Pasaribu, V. L. D., Rahayu, S., Septiani, F., \& Metarini, R. R. A. (2021). Mompreneur Penopang Perekonomian Keluarga Di Masa Pandemi Covid-19 Dengan Bisnis Online Pada Kelurahan Pondok Benda. Jurnal Pengabdian Kepada Masyarakat, 2(1), 75-82. http://www.openjournal.unpam.ac.id/index.php/JA L/article/view/8776

[11] Tuwu, D. (2018). Peran Pekerja Perempuan Dalam Memenuhi Ekonomi Keluarga: Dari Peran Domestik Menuju Sektor Publik. Al-Izzah: Jurnal Hasil-Hasil Penelitian, 13(1), https://doi.org/10.31332/ai.v13i1.872

63.

12] Liana, Y. (2016). Peran Ibu Dalam Meningkatkan Pendapatan Keluarga Untuk Menanggulangi Kemiskinan. Dinamika Dotcom: Jurnal Pengembangan Manajemen Informatika Dan
Komputer, $\begin{array}{ll}\text { Komputer, } & 7(2), \\ \text { http://ejurnal.stimata.ac.id/index.php? journal=DIN }\end{array}$ AMIKA\&page $=$ article\&op $=$ view\&path[] $=201$

[13] Ravn, M., \& Simonsen, T. A. S. (2020). Master ' Thesis / Bachelor 's Thesis. MASTER'S THESIS Study, 49(89), 15242 